\title{
Unhappy Offspring? Concubines and Their Sons in Early Abbasid Society MATTHEW GORDON
}

Department of History, Miami University, Oxford, Ohio; e-mail: gordonms@miamioh.edu

doi:10.1017/S0020743816001215

Contemporary and later Arabic texts provide much evidence that wayward conduct by elite young adult males was a source of considerable stress in early Abbasid cities. ${ }^{1}$ This brief essay turns on a question: to what extent is such conduct to be attributed to concubinage? I treat two sample texts, each describing untoward activity on the part of well-placed adult sons and its impact on the Abbasid body politic. Neither text, however, speaks to concubinage. What follows, then, is an argument from circumstantial evidence. Concubinage seems a most likely source, and so can reasonably be connected to the broader patterns of social disjunction of the first Abbasid period (roughly the mid-8th to mid-10th centuries).

There is little question that elite Abbasid households absorbed large numbers of young enslaved women. These women were provided by well-established commercial networks drawing on the populations of a variety of regions bordering the Arab/Islamic Empire. The numbers of these enslaved women are impossible to measure. So, too, is the extent to which the pattern of integration of slave women into households characterized society at large, that is, social ranks below that of the imperial 1 percent (the caliphs, their officials and clients, elite merchants, and the like). But how well has modern scholarship dealt with the dynamics that followed on the formation of complex households in which enslaved women played a considerable role?

Much turns, needless to say, on the forms of labor demanded of the young women. The majority were likely recruited for domestic labor about which medieval Arabic writers show little interest: hardly anything can be said about the "mundane" affairs of Abbasid city-dwellers and those in their employ. A smaller number of women were either acquired expressly as concubines or came to that standing as a result of relationsforced or voluntary - with male (and, indirectly, female) owners. Nadia Maria El Cheikh has recently commented on the ubiquity of elite concubinage in this period, as did Leila Ahmed in an earlier work, though in less measured fashion. ${ }^{2}$

Among the many Abbasid-era texts mentioned earlier that share a preoccupation with wayward sons, a subset treats conduct by leading males of significant households in which concubines were present. Two such texts will be considered here. At issue is whether the dysfunction that befell both houses is to be laid at the door of concubinage.

The first text is a letter attributed to Ahmad ibn Tulun (d. 884), the founder of a dynastic house of late 9th-century Egypt. As was typical of men of his station, Ibn Tulun owned some number of concubines, and appears to have produced sons with at least three. The letter in question survives in corrupt form in Sirat Ahmad ibn Tulun (The Career and Achievements of Ahmad ibn Tulun), a 10th-century biography of the governor attributed to al-Balawi (fl. second half of the 10th century). ${ }^{3}$ A more polished version survives in the well-known Mamluk-era compendium on the chancery of al-Qalqashandi (d. 1418). ${ }^{4}$ 
The letter is addressed to al-Abbas, Ibn Tulun's eldest son and designated heir. Around 878, al-Abbas seized the opportunity of his father's absence from Egypt to raise an army and strike out on his own. He marched into Ifriqiya where, after sowing much havoc, he was routed by local forces and escorted by Tulunid officers back to Egypt. The letter dates to shortly before his defeat.

In treating the letter, there is the question of al-Abbas's background. Al-Balawi identifies al-Abbas as the son of one of Ibn Tulun's wives, she the daughter of Yarjukh (d. 872), a Turkish commander of Samarra and early patron of his father (Ahmad ibn Tulun). Al-Abbas, in other words, was the son of a free woman, not a concubine. Following his ostensible rebellion, Ibn Tulun replaced him as heir apparent with the younger Khumarawayh, who was. (Khumarawayh seems to have later arranged for alAbbas's murder.) One point, then, is that, in treating the offspring of concubines, the careers of their free siblings or half-siblings matter as well. It is a matter of the impact on households, not simply individual careers.

Among the notable features of the letter is its tone. Wadad al-Qadi has pointed out that the text is highly charged and personal, which distinguishes it from the typically detached and polished discourse of medieval Arabic court letters. ${ }^{5}$ There is a tension at work in the letter: rage on the one hand, and a weary determination to restore order on the other. It sounds a universal note: a father is shamed by the conduct of his offspring and is keen to see things right despite the cost involved. Scattered through the letter are references to familial dynamics. Ibn Tulun, at one point, threatens to strip al-Abbas of his nisba, the "noun of relation" that made up a typical proper name. Its removal meant that ties were severed: al-Abbas would be shorn of family and kin. The letter throws salt in the wound by quoting a Qur'anic phrase of the person "forgotten, utterly forgotten" (Surat Maryam, 19:23). Finally, late in the text, Ibn Tulun curses his son directly, wishing that he-al-Abbas-would one day himself suffer the consequences of a male offspring's untoward behavior.

The second text is contained in the Ta'rikh (History) of al-Tabari. It is the opening section of an extended account of the succession arrangement by Harun al-Rashid (r. 786809) for his three sons. ${ }^{6}$ There is good reason, in fact, to consider the entire succession plan here: what followed al-Rashid's careful arrangements and his death, after all, was civil war between the two eldest brothers, al-Amin (r. 809-13) and al-Ma'mun (r. 81333). The latter, the eldest of eleven sons, was the offspring of an Afghani concubine, though raised by an Abbasid queen mother (the famous Zubayda).

His brother (al-Amin), by constrast, was among the very few Abbasid caliphs born to free mothers; one source indicates that he was only one of two such caliphs, the others born, in other words, to concubines. ${ }^{7}$ The two half-brothers, if in different ways, were given to controversy. In al-Amin's case, if one accepts many comments by medieval Arab authors, it was his immoral conduct: the young caliph—so read the charges-had few of the inhibitions presumably expected of well-appointed sons and caliphal heirs. ${ }^{8}$ In the case of his brother, al-Ma'mun, it was more a seeming dependency on political gamesmanship, the challenge to his brother (and the resulting civil war) one of several examples. ${ }^{9}$

The opening of al-Tabari's account reads like commentary on the wisdom of the succession scheme (although it can be very difficult to know just what the historian intended in situating sensitive material as he did). The device is poetry: al-Tabari provides 
two selections of verse that welcome Harun al-Rashid's nomination of al-Ma'mun and the third, less well-known son, al-Qasim (al-Mu'taman, born to another of al-Rashid's concubines). He then comments that popular opinion was divided: those who accepted the succession plan were rebuffed by many others, identified as "from the common people." The latter view held that as soon as the father died, the brothers would turn on each other, as in fact they did. These lines derive from twelve stanzas of verse that follow:

[The caliph] intended, by doing this, that he might remove from among his sons/ the causes of dissension, and that they might give free rein to amicableness/But he has implanted unremitting enmity and has bequeathed a legacy of divisiveness. ${ }^{10}$

These texts are but two sources of evidence. Each connects wayward sons with a set of patterns: ill-considered behavior of young men, be it the transfer of filial loyalties, the turn to an impious lifestyle, or the decision to take up politically disruptive activity; the impact of these choices on family bonds and networks; and the resultant strain on society at large. The two texts come together around these issues.

Julia Bray provides valuable ideas on how best to get at the origins of this anxiety, modeling as she has the use of Arabic literary texts for Abbasid social history. In reference to urban households and their male denizens, she speaks of the "precariousness of male roles," 11 which she connects to the emergence of complex, mixed-status Abbasid households into which slaves were often closely integrated, through concubinage among other means. ${ }^{12}$ She holds that the resulting social currents undercut typical male roles in politics and the military. The outcome was a greater sense of vulnerability: elite males had now, as Bray puts it, "to make difficult, compromising choices if they were to extract advantages from the power structure and perpetuate them through their families." 13

Reflected here, in part, is an argument developed by Patricia Crone regarding the dissociation of urban society from politics and government precisely in this period. ${ }^{14}$ She relates this dissociation to the recruitment by the early Abbasid caliphs of the notorious slave military. (These caliphs were the offspring of Harun al-Rashid: alMa'mun and another brother, al-Mu'tasim, himself born of a second-generation Kufan slave mother.) ${ }^{15}$ Many questions surround this decision and its impact on Abbasid history. The point is that the transfer of arms to culturally and politically "alien" forces explains the inability of urban, military-age males to exploit normal career options in the armed forces and government.

There is much to agree with here. To borrow again from Bray: "debarred from the exercise of physical force by the increasing professionalisation of the caliph's army ... the competence of the metropolitan Abbasid male... was effectively limited." ${ }^{16}$ But more needs to be said about concubinage. One clue is a repeated concern in contemporary texts with father-son relations. In both cases considered here, the prestige and fortunes of the household are at issue. It becomes a question of reconstructing the dynamics of important, Abbasid-era households. The task is not easy: medieval Arabic authors generally ignored "private" or interior household arrangements.

Concubinage, in any case, was woven into Abbasid-era domestic, social, and political affairs. Scholars of early Islamic law have shown that concubinage was the subject of debate by Abbasid-era jurists; the concubine mother-the umm walad-is a topic of medieval Islamic jurisprudence. ${ }^{17}$ Equally valuable are discussions of the ascendance of concubine mothers, notably the Abbasid queen mothers, Khayzuran, Qabiha, and 
Shaghab. ${ }^{18}$ Their route to influence began with the bearing of male offspring and the likelihood that they acquired the standing of umm walad. Relationships bound them to their masters (the fathers); the networks that sustained them; their male offspring; and, it can only be assumed, the free women of these households, though, sadly, the Arabic sources say little on this score.

Modern scholarship is less helpful, however, regarding the male offspring, with the exception of Julia Bray's work. It is worth considering two elements of Abbasid-era concubinage. The first is an apparent pattern of competition by which given sons were promoted by their mothers and their retinues. The aim, presumably, was to seat younger men that were susceptible to influence. The pattern pertains to the highest imperial office - the caliphate-where one sees rivalries over succession playing out over and again. The same pattern can be identified for local courts (e.g., the Tulunids of Egypt) but more needs to be done to identify its impact on elite households more generally. The point is that concubinage produced the conditions by which for every one male promoted to positions of influence there were many others that were simply pushed aside, thus left with little or no standing at all.

The second ingredient is paternity, specifically its acknowledgement by the pater familias. It goes to the wider topic of the umm walad. Modern studies of the latter institution indicate that Abbasid-era jurists and scholars discussed it at some length. The full discussion cannot be entered in here. Suffice it to say that debate over the standing and rights of the concubine mother turned in good part on the question of paternity and its acknowledgment. The sense is that fathers/masters could deny paternity at any point in time, a decision that returned the offspring to the slave standing of their mothers. Such a gesture on the father's part, in sum, undercut full access to the prestige and wealth of the household: the son's fortunes were now much reduced.

How often this took place is impossible to determine, and Jonathan Brockopp points out that the medieval jurists devote far more attention to the mothers (the ummahāt al-awlād) than they do the children. Consideration is also to be given to fathers who ignored regulations regarding paternity. After all, medieval sources mostly concern themselves with elite society, a "class" of families able to skirt the law (or find legal sanction) when it suited them. And, in many cases, questions arising from paternity and its acknowledgment involved the transfer of wealth, whether in the case of inheritance or of profit earned through the sale of slaves, so the stakes were high.

The argument here, using but two texts, is that without joining concubinage to sociopolitical dissociation, an explanation of the affairs of Abbasid-era sons falls short. Concubinage shaped domestic arrangements in Abbasid urban households, providing opportunity to fortunate sons, and leaving others with limited recourse to influence and wealth. It would follow, in other words, that a population of young males was left without proper access to guidance and livelihood. Concubinage could, and often did, have the effect of creating fractured, divided households. The result was the creation of an unruly male element.

\section{NOTES}

Author's note: I thank Alexis Wick and Dahlia Gubara for their helpful comments on the first draft of this paper. 
${ }^{1}$ See Julia Bray, "Men, Women and Slaves in Abbasid Society," in Gender in the Early Medieval World, ed. Leslie Brubaker and Julia M. H Smith (Cambridge: Cambridge University Press, 2004), 121-46.

${ }^{2}$ Nadia Maria El Cheikh, Women, Islam and Abbasid Identity (Cambridge, Mass.: Harvard University Press, 2015): 6-7; Leila Ahmed, Women and Gender in Islam (New Haven, Conn.: Yale University Press, 1992): 83-85.

${ }^{3}$ Sirat Ahmad ibn Tulun, ed. Muhammad Kurd 'Ali (Damascus: al-Maktaba al-'Arabiyya, 1939), 260-64.

${ }^{4}$ N.e. (Cairo: al-Matba' a al-Amiriyya, 1331-38/1913-19), 7:5-10.

${ }^{5}$ I was fortunate enough to have attended two courses taught by Professor al-Qadi at Columbia University (1985-86), in one of which we studied the letter. My comment is drawn from class notes.

${ }^{6}$ Muhammad Abu al-Fadl Ibrahim, ed., Ta'rikh al-Tabari (Cairo: Dar al-Ma'arif, 1960-68), 8:275-77. See also C. E Bosworth, trans., The History of al-Tabari, vol. 30, The Abbasid Caliphate in Equilibrium (Albany, N.Y.: State University of New York Press, 1989), 179-83.

${ }^{7}$ See Ibn Hazm, Risala fi Ummahat al-Khulafa', ed. Ihsan Abbas (Beirut: al-Mu'assasa al-'Arabiyya, 1981), 120-21.

${ }^{8}$ For a close reading of these accounts, see Tayeb El-Hibri, Reinterpreting Islamic Historiography: Harun al-Rashid and the Narrative of the Abbasid Caliphate (Cambridge: Cambridge University Press, 1999): 59-94.

${ }^{9}$ For two accounts, see ibid., 95-142; and Michael Cooperson, al-Ma'mun (Oxford: Oneworld Publications, 2005), esp. 39-79.

${ }^{10}$ See Bosworth, Equilibrium, 182.

${ }^{11}$ Bray, "Men, Women and Slaves," 142.

${ }^{12}$ Ibid., 136.

${ }^{13}$ Ibid., 142.

${ }^{14}$ Patricia Crone, Slaves on Horses: The Evolution of the Islamic Polity (Cambridge: Cambridge University Press, 1980), 74-81.

${ }^{15}$ Ibn Hazm, Ummahat, 120.

${ }^{16}$ Bray, "Men, Women and Slaves," 141.

${ }^{17}$ See Kecia Ali, Marriage and Slavery in Early Islam (Cambridge, Mass.: Harvard University Press, 2010); Jonathan Brockopp, Early Maliki Law: Ibn 'Abd al-Hakam and His Major Compendium of Jurisprudence (Leiden: Brill, 2000); and Ingrid Mattson, A Believing Slave Is Better Than an Unbeliever (PhD thesis, University of Chicago, 1999).

${ }^{18}$ See Nadia Maria El Cheikh, "Gender and Politics in the Harem of al-Muqtadir," in Gender in the Early Medieval World: East and West, 300-900, ed. Leslie Brubaker and Julia M. H. Smith (Cambridge: Cambridge University Press, 2004), 147-61; and Hugh Kennedy, The Court of the Caliphs: The Rise and Fall of Islam's Greatest Dynasty (London: Weidenfeld \& Nicolson, 2004): 160-99. 